\title{
IKONOGRAFIA DUCHA SW. W OKRESIE PATRYSTYCZNYM
}

Ikonografię Ducha Świętego w okresie patrystycznym można rozpatrywać w trzech grupach przedstawieniowych. Są nimi: symbole biblijne, ujęcia liczbowo-symboliczne oraz przedstawienia antropomorficzne. Ramy czasowe omawianych przedstawień obejmują okres od III do końca VI wieku. Przykłady przedstawień pochodzą zarówno z zachodniej, jak 1 ze wschodniej części Imperium Rzymskiego.

\section{SYMBOLE BIBLIJNE}

Pismo Swięte dla zobrazowania obecności Ducha Swiętego używa dwu symboli: $g$ o 1 e b i c y 1 p $\mathbf{1}$ om y k 6 w o g n $1 a^{1}$. W scenie chrztu Jezusa,Jan Ewangelista pisze: "Ujrzałem Ducha, który jak gołębica zstęporał z nieba 1 spoczął na Nim" /J 1, 32/2. Podobną relację daja synoptycy: "/Jezus/ ujrzał Ducha Bożego zstępującego jak gołębicę" / Mt 3, 16/, "Duch Swiety zstąpił na Niego w postaci cielesnej niby gołębica" / tk 3, 22/, "W chwil1,gdy wychodził z wody ujrzał rozwierajęce się niebo i Ducha jak gołębice zstępującego na siebie" /Mk 1, 10/.

Tertullian w traktacie "O chrzcie" tak wyjaśnia ten sposób obrazowania:

"Duch najświętszy od ojca /.../ zstąpił również postaci
gołębicy na Pana. Wówczas to objawiła się natura Ducha

1 Bioıijnym symbolem Ducha Swiętego jest téz strumień żywej wody j7, 38. W ikonografii symbol ten występuje głównie w scenach chrztu świętego.

2 Tekst Jana nawiazzuje do formuły Izajasza 61, 1 "Spiritus Domini super me" oraz do obrazu stworzenia świata/Rdz 1, 2/: "Duch Boży unosił się nad wodami". Te formuły zilustrowane zostana w 1konografil znacznie później, dopiero w sztuce romańskiej. Gołębicę siedząca na głowie Chrystusa - ustawioną w takich scenach profilem i ze złożonymi skrzyłłami - widzimy np. na portalu kościoła Norbertanek w Strzelnie por. T. Dobrzeniecki, Majestas Domini, "locz- 
W ikonografii gołębica nie zawsze oznacza Ducha Świętego. Był ona dawnym antycznym symbolem pokoju i miłości oraz personifikacją różnych cnót 1 usposobień, a także ptakiem ofiarnya u Izraelitów ${ }^{6}$. W ikonografii może również występować jako obraz duszy ludzkiej, ja ko ogólny znak interwencji Bożej/np. w sc nach ukazujących Trzech Młodzieńców w piecu ognistym lub Daniela między lwami/, a w liczbie 12 moze symbolizować 12 apostołów.

Gołębica jako symbol Ducha Swiętego występuje w scenach chrzt bierzmowania, zwiastowania i Zesłania Ducha Śwį̨tego. Najwcześniejs: dotychczas znanym, przedstawieniem chrztu Pana Jezusa jest malowidł. datowane na ok. 220 r., zdobiące ściane cubiculum X, w tzw. kryptaol Lucyny w katakumbach Kaliksta. Scena, ta jest inna niż pózniejszy schemat i zdaje się ilustrować tekst ewangelii św. Jana: młodzieńcz: Jezus wychodzi z rody na brzeg rzeki, na którym stoi Jan Chrzciciel pochylający się ku Niemu. Obaj ukazani są w profilu, a nad głową Je. zusa unosi się gołąb, też w profilu.

Pewnego rocizaju schehat sceny chrztu katechumena ukazuje go jako dziecko stojące w wodzie lub obok spływajacego strumienia wody, któremu chrzciciel kłauzie dłoń na głowie ${ }^{7}$. Nad sceną unosi się lub spływa gołębica. Nałożenie rąk zdaje się być,zdaniem większości badaczy, uwidocznieniem jednoczesności udzielania obu sakramentów $w$ on wianym okresie ${ }^{8}$.

Sceny, w których występują w podobnym układzie gołębica i impc sitio manuum, a nie występuje woda są - być może - osobnym znakiem sakramentu bierzmowania ${ }^{9}$.

6 Por. F. Suhling, Die Taube als religiosessymbol in christlichen Altertua, Munster 1930; B. D. Beck, RGG II 1290; A. Quaquarelli, Lo Spirito Santo e la iconografia del II e III secolo, VCh 16/197 175-193. Niestety nie udało ini się wykorzystać najnowszej pracy $n$ ten temat: A. Fausone, Der Taufe in der frthchristliche Sepulkral kunst, Città del Vaticano 1983.

7 Por. np. Sarkofag $z$ kościoła Santa Maria Antiqua z poł. III w. lu bok sarkofagu z irles z pol. IV w. ilustrowane w pracy: B. Filars Poczįtki sztuki chrześcijańskiej, Lublin 1986, fig. 161 i fig. 19

8 Por. L. de Bruyne, L'imposition des mains dans l'art chrétien ancienue, hivac $20 / 1943 / 212-246$.

9 Na przykład na surkofaru z ilas d'Aire z pocz. IV w. ilustrowanym, Poczutiki sztuki clirzescijasiskiej, dz.cyt., Pig. 166. 


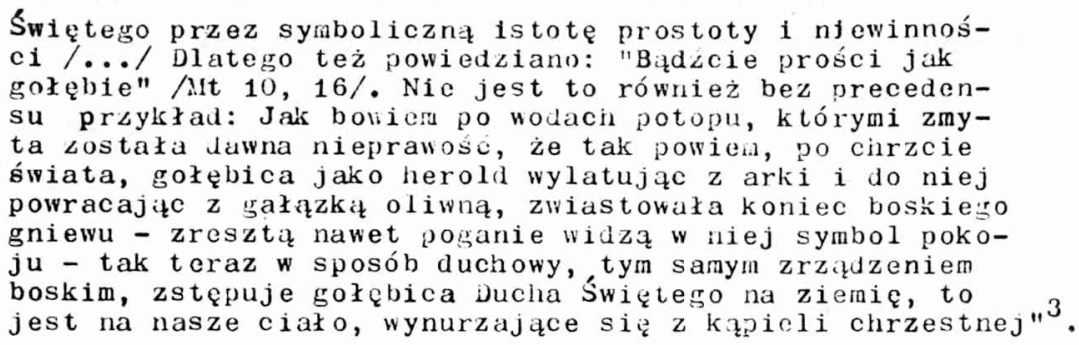

liołębice Noego jako typ gołębicy z cirztu Chrystusa intermretu-

je tez w swej katechezie Cyryl Jerozolimski:

"jak bowiem za czasów Noego/.../ grołębica wróciła wieczorem do Noego z gałązką oliwną, tak też zstąpił Duch Swięty na prawdziwego Noego, Stwórcę drugriego pokolenia, który różne naroly, przez różne rodzaje zwierząt, w arce wyobrazone, złizczył razem /.../ /w Kościół/"4.

Obrazu gołębicy jako potwierdzenia obecności Ducha Swiętego używa także Euzebiusz z Cezarei, kiedy opisując wybór papieża przez kolegium biskupów podaje, że nagle nad głowaz bliżej nieznanego biskupom Fabiana ukazała się gołębica, w której rozpoznano wolę Boga ${ }^{5}$.

nik Muzeum Narolowego w Warszawie" 19/1975/ 192. W scenie stworzenia świata gołęhica występuje dopiero na mozaice S. Niarco w iVenecji w XIII wieku. T. Dobrzeniecki zwraca uwagę, że spostrzeżenie stanowiące podstawę tej, pózniej wykształconej, ikonografii siormułował już EPren Syryjczyk /Hymn na Ĺpifanię 9, 1/ pisząc o Janie Chrzcicielu: "vidit Spiritun super caput Filii inanenten, ut dewonstraretur supreman maiestatem".

3 De baptismo 8, 3-4, CCL 1, 283, tłum. E. Stanula, PSP 5, 141. W relacji Tertulliana zarysowane są wszystkie ważne elementy interpretacji symbolu gołębicy: charakter typu, jaki ma w scenie z arka Noego, jej pogańska geneza oraz znaczenie gołębicy jako personifikacji cnót.

4 Catechosis 17, 10, PG 33, 981, tłum. W. Kania, PSP 9, 265. W malarstwie katakumb rzynskich często występuje scena ukazująca gołębicę ponad arką Noego. Gołębica jest interpretowana najczęściej jako znak interwencji Bożej, a arka jako typ Kościoła.

5 Por. Historia ecclesiastica VI 29, SCh 41, 131, POK 3, 284: "Gdy się wszyscy bracia zgromadzili celei dokonania wyboru przyszłego następcy na stolicy biskupiej/.../ tedy jak wieści niosą, z wyżyn spłynęła nagle gołębica i spoczęła na głowie jego, dając żywe wyobrazenie zstąpienia Ducha Swiçtego na Zbawiciela w postaci gołębicy". 
Późniejsze przedstawienia, jak nip. mozaika z baptysterium arian w Rawennie z końca $V$ w ukazują chrzest Chrystusa w formie nieco skostniałej, a zarazem bogatszej w detale ikonograficzne. Miniatury kodeksów z VI w. ukazują nad sceną chrztu Chrystusa pełną teofanię: nad Chrystusem unosi się gołębica, a nad nią wysuwa się z chmur Manus Dei ${ }^{10}$.

Drugim wydarzeniefi ewangelicznym oddawanym w ikonografii omawianego okresu, w którym gołębica może byé jednoznacznie interpretowana jako symboliczne przedstawienie Ducna Swiętego, jest scena Zwiastowania. " jej opisie czytany: "Duch Święty zstąpi na Ciebie i moc Najwyższego osłoni Cię" / Lk 1, 35/. Wspaniałą ilustracją tej sceny jest nozaika łuku triumfalnego bazyliki Santa laria Maggiore w Rzymie z ok. 430 roku. W górnya rzędzie, po lewej stronie, widzimy Najświętszą Maryję Pannę bogato odzianił, siedzaca na tronie, w otoczeniu czterech aniołów. Arcianioł Gabricl, unoszący się w obłoku, zwiastuje Jej wielką nowinę. W kierunku Maryi spływa z obłoków biała gołębica.

IV scenie Zesłania Ducha Świętego, której najdawniejszy przykiad zaciował się w Lirangeliarzu labuli z 586 r. /Biblioteca Laurentiana we Florencji/, występuje i gołębica i jęzýsi ognia.

W relacji Dziejów Apostolskich / $2,3 /$ mowa jest tylko o językach ognia: "Ukazały się im też języki jakby z ognia, które się rozdzieli$ł y, \quad i$ na każy̆a z nich sroçał jeden. I wszyscy zostali napełnieni Duchem Świętym". Obecność w scenie gołębicy jest dowodem utrwalenia się pierwszej symboliki trwającej zresztą do daisiaj. W kodeksie Rabuli po dwu stronach jziewicy stoją apostołowie w dwu symetrycznych rzędach. Nad głową każdego z nich unosi się język oģnia. Płomieŕ nad głową Maryi Panny wyciıodzi jak gủyby z dziobka unoszącej się nad Nią gołębicy z rozpostartyani skizydłami. Interpretając tę scene Marie Louise Thérel zwraca uwage na suchiz i raezej uỉoga kompozycję co jest - jej zdaniem - lowodem, ze artysta nie iniał zadnych wcześniejszych wzorców i ukształtował scenę w stylu epoki. Frontalne ustawienie apostołów i surowość ich postawy są jeszcze wzmocnione monotonnym rytmen takich

10 Por. J. Lngeranu, Lu len Dreifaltigskeitsdarstellungen der Prahchristlicien kunst: Gats es im 4. Jinrhuniert anthropomorphe Trinitatsbilder? JbAC 19/1076/ tail. 19 A. Lirabar, Christian iconography. A study of its origins, s.inceton 1y65, 91 ris. 233 /koleks armeński z Eczmiadiı/. 
samych aureoli ${ }^{11}$. O tych języaci ogria pisal juź wcześniej Efre Syryjczyk w hymie o suchu Świętyu:

"/.../ ożywiają się usta oraz język jak ogniste języki, co spoczęły na uczniac:. Ciepłcm przez języki wypęuził Duch Święty wilczenie z uczniów/.../ Duch Święty złamał siłe zimna ognistyui jezykami i wygnał z uczniów bojazin"12.

Biblijny syubol gołąbicy josłużył, obok dwu innych biblijn: symboli, jakimi są: Manus Dei - symboliczne przedstawienie Boga. i baranek - syaboliczne przedstarienie syna, do konstruowania naj. dawniejszych przedstawień 'Trójcy Śwį̧tej. Pojawiają się one na pj łomie IV i V w. wyránie dla dekoracji absyd kosciołów stanowiąc oprawę ołtarza. Te najdawniejsze znamy $z$ opisów Paulina z Noli $i$ konanych na ich podstawie rekonstruicji. Paulir, biskup i poeta, też inicjatoreni wprowadzenia przedstawień biblijnych do dekoracj. whętrz kościelnyoh, które miały pełnić wyrazną funkeję dydalityczı 7 liście do przyjaciela, biskupa Sewera z Primaliacum, hreśli syl: boliczny obraz Trójcy świłtej, ktoryli przyozdobiz absydi nowo wzr sionej bazylikipray grobie si. Feliksa:

\footnotetext{
"Pleno coruscat Trinitas mysterio:

Stat Christus ayno, vox Patris coelo tonat Et per columban Spiritus sanctus fluit, Crucem corona lucido cingit globo"13.
}

Rekonstrukcje tej nozaiki wykonał Wickhoff $i$ jest ona do dzisiaj ogólnie przyjąta ${ }^{14}$. Poza symioliczno-riguralnym ujęciem Trójcy Siw tej, nowatorska w tej scenie jest teci kolista osłona świetlna/lu cidus glowus/, otaczającakrzyż i bęląca jednym z pierwszych przy kładów manaor 1 , wających za zadanie uwiciocznienie transcentencji Boga.

11 M. L. Thérel, Les symboles de l'Ecclesia dans, la création ico graphique de' 1 art chrétien du III au VIe siècle, Roma 1973,

12 Hymnus de Spiritu Sancto, CSCO Syr 159, 226, tłun. W. Kania, Pieśni pustyni syryjskiej/GL 4/, Tarnów i980, 21.

13 Epistula 32, 10, CSLL 29/1 286.

14 Por. Josef Engemann, Zu den Apsis-Tituli des Paulinus von Nol: JbAC $17 / 1974 / 23-25$. 
Z tego samego listu Paulina z Noli znany jest też opis programu absydy bazyliki z Fundi w Lukani :

"Sub cruce sanguinea niveo stat Christus in agno /.../ Alite quem placida Sanctus perfundit hiantem Spiritus et rutila Genitor de nube coronat"15.

Wspaniały tron z krzyżem na poduszce, stojący na rajskim pagórku z Barankiem, jest tu symbolicznym przedstawieniem męki $i$ chwały Chrystusa. Nad tronem gołębica Ducha Swiętego, a wyżej Manus Dei trzymająca wieniec chwały ${ }^{16}$.

Podobne ujęcie figural no-symboliczne zachowało się na nieco późniejszej mozaice z kaplicy Santa Matrona in Santa Prisca Wapua Vetere: na mozaice lunety ukazany jest pusty tron symbolizujący Boga ojca. Na poduszce tronu leży księga Pisma Świętego reprezentująca Syna Bożego, a na oparciu tronu siedzi gołębica Ducha Świętego ${ }^{17}$.

\section{UJECIA LICZBOWO-SYMBOLICZNE TRÓJCY ŚWIETEJ}

W tego rodzaju ujęciu przez podkreślenie znaczenia liczby trzy, jedność trzech Osób Boskich została wyrażona trzykrotnie powtórzonym znakiem lub przedmiotem ${ }^{18}$. Na symbolikę trójkąta jaḱo znaku doskona-

15 Epistula 32, 17 , CSEL $29 / 1292$.

16 Jest to rekonstrukcja Ch. Ihm. Opis i interpretacja por. J. Engetnann, $\mathrm{Zu}$ den Apsis-Tituli, jw., 26-30.

$17 \mathrm{~J}$. Engemann, jw. S. $44 \mathrm{fig} \cdot 7^{\mathrm{b}}$. Na tej samej tablicy autor pokazuje też ciekawy przykład z Konstantynopola z kościoła Hagia Sophia z VI wieku. Jest to fragment dekoracji brązowych drzwi: w obramowaniu utworzonym przez dwie kolumny spięte łukiem stoi tron, na nim stoi otwarta księga z greckim tekstem ewangelil św. Jana: "Ja jestem brama do owczarni" /J 10, 7/. Nad księga frontalnie umieszčona jest gołębica z rozłozonymi skrzydłami.

18 Te dosyć sztuczne próby nie przyniosły dobrych rezultatów. Jest to potwierdzeniem stwierdzeŕ, sformułowanych przez ks. prof. W. Hryniewicza, uwidaczniających znaczenie teologi apofatycznej w próbach poznania, a więc i oddania tajemnicy Trójcy Swiętej. Pisze on m.in. /Eń I 746/: "Apopatyzm wyklucza w teologii wszelką abstrakcję i czysto intelektualne poznanie dostosowujące tajemnice wiary do wymiarów niyśli ludzkiej; u jego podstaw leży bowiem przekonanie o niemóności poznania Boga jako przedioiotu/.../ prowadzi do 
łości zwrócił uwagę już św. Augustyn ${ }^{19}$, ale w sztuce motyw trójkąta pojawia się dopiero w sztuce romańskiej.

WW sensie liczbowo-symbolicznego ujęcia Trójcy interpretowany jest potrójny chrystograu, zdobiący sklepienie baptysterium w Albenga, datowany na VI wiek. W trzech świetlistych okręgach powtórzony jest Monograul Plankowany przez alfę i omege. Mrażenie jedności sprawiają nakładające się na siebie odcinki ramion chryzm. Symbolem Ducna Swiętego jes ówiatło przenikające wszystkie trzy okręgi. 20.

\section{PRZEUSTAWILNIA ANTIOPONUTFICZNE TRÓJCY SWIETEJ}

Problem onówił krytycznie J. Lingemann uwidoczniając dwie grupy tego rocizaju przedstawies: typologiczne, jakim jest w $\mathrm{i} z \mathrm{y} t \mathrm{a}$ A $n i o ł o ́ w ~ u \quad A$ b $r$ a h a m a oraz zwiazzane z tekstem Ksiegi

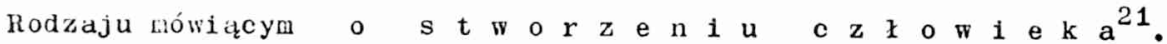
Ĺngemann uważa oba ujęcia za nie odpowiadające wymaganiom współczesnej krytyki naukowej.

W opisie biblijnym wizyta pod dębem Mambre ma niewątpliwie charakter teofanijny /Rdz 18, 1-3/. Abrahain zwraca się do trzech przybyszów jak gdyby byli jednym: "Panie jeślim znalazł łaskę w oczach Twoich nie rajaj sługi Twego". Św. Augustyn opisuje tę wizytę wastępujących słowach: "Tres vidit et unum adoravit"22.

Najstarsze znane przedstawienie tej wizyty pochodzi z hypogeum przy via Latina $i$ jest datowane na lata $320-350^{23}$. Zdobi prawe arcosolium w cubiculum $B$, umieszczonym na zakończeniu pierwszego korytarza. Do siedzącezo starego Abranama, czyniącego prawą ręką gest mówienia, wyciagają prawe dłonie trzy postacie stojące duzo wyżej. Wszystkie ubrane są $w$ białe płaszcze, ale kazda jest inna. Scena jest pełna żywości, ujęta jupresjonistycznie.

poznania osobowej tajelunicy Trojjcy Świçtej/.../".

19 Contra Faustum 20, 6, PL 42, 371.

20 Por. F' van der Meer, Atlas de 1'Antiquité Chrétienne, Paris 1960, Pig. 414.

21 Zu den vreiftligskeitsuarsteliunisen, art.cyt., 157-172.

22 Contra Maxilitanum 7, RL 42, 809.

23 Ilustrowane m.in. w "Les dossicrs de l'archéolorgie" 18/1976/ 104 . 
Drugi, bardziej znany przykład pochodzi z bazyliki Santa Maria Maggiore w Fzymie /432-440 r./, zajmuje jedno z pól mozaikowych w cyklu patriarchów, zdobiącego nawę główną kościołá. Kompozycja sceny jest dwupasora. U góry Abraham w pokłonie wyciągniętą prawą rękaz wita zbliżającyci się trzech przybyszów. Postacie są różne, ale każa spowita jest białym płaszczem i ma aureole. Postać środkowa ukazana jest na tle owalnej świetlistej mandor $1 i^{24}$. U dołu Abraham i Sara usługują gościon siedzącym za stołem i zróżnicowanym jedynie gestam1 rạk. Postacie tak tu, jak $i$ wierwszej scenie nie mają skrzydeł.

Podobne, ale bardziej konwencjonalne ujęcie ma scena zdobiąca boczną ścianę prezbiterium kościoła San Vitale w Rawennie /525-532 $x \cdot /$.

Znacznie bardziej dyskutowana jest scena ilustrująca stworzenie człowieka / $\mathrm{Rdz} 2,8$ i 2, 21-22/. Do niedawna znano tylko jeden przykład takiej sceny występujący na tzw. sarkofagu dogmatycznym znalezionym pod konfesją bazyliki św. Pawła w Rzymie i datowanym na lata $330-360^{25}$. Scena umieszczona jest na lewej krawędzi górnego pasa dekoracji. Siedzący na tronie starzec układem palców prawej ręki /trzy złożone, a wskazujący i środkowy wyprostowane/ czyni gest błogosławieństwa nad leżącą przed tronem postacią nęską. Taki sam mężczyzna, znajdujący się przy nim, kładzie rękę na głowie stojącej przed tronem kobiety. Trzecia analogiczna postać, w której część badaczy dopatruje się Ducha Swiętego, a część interpretuje jako świadka sceny, znajduje się za tronem. Głowy postaci bocznych zwrócone sa ku środkowej. W 1974 r. znaleziono w Arles przyklad drugiej niemal takiej samej sceny 26 . W obu sarkofagach pod sceną stworzenia znajduje

24 Postać w mandorli jest interpletowana także jako objawiajacy gic Logos w asyście dwóch aniołów. Por. K. Wessel, w: Reallexikon zur byzantinischen kunst I $18-19$.

25 Por. Początki sztuki chrześcijańskiej, dz•cyt•, fig. 173.

26 Sarkofag jest publikowany przez J. Engemanna, Zu den Dreifultigskeitsdarstellungen, jw., s. 164-170, tabl. 10-14. Na tym sarkofagu i Adam i Ewa stoja przed trzema postaciami, z których pierwsza trzyma dłoń na głowie Lwy i rozmawia z drugą siedzącą. Trzecia osoba trzyma się za oparcie krzesła i spogląda na dwie pozostałe. W scenę włączona jest jeszcze jedna osoba, która stoi za Adamem i ręką jak gdyby przysuwa go do Ewy. Głowę zwróconą ma ku "trzem". 
się Maryja z Dzieciątkiem siedząca na tronie, za którym sto1 taka sama postać jak w górnym rzędzie.

Nie ma rzeczywiście żacinych pewnych wskaźników, którè by poz:valały określać jednoznacznie trzy osoby uczestniczące w akcie stworzenia jako trzy osoby Boskie $e^{27}$. Interpretacja taka jest jednak nie tylko możliwa, ale wręcz się nasuwa. Oczywiście, nie można doszukiwać się $w$ tej scenie żadnych treści doktrynalnych, a jedynie ilustrację opowieści o ulepieniu człowieka przez Boga, który sam o sobie mówi w liczbie mnogiej: "Uczyńmy człowieka na nasz obraz, podobnego Nam" $/$ Rdz $1,26 /$.

Cickawa jest argumentacja L. de Bruyne'a, który tłumaczy taki schemat sceny nawiązaniem do znanych przedstawień antycznych lepienia człowieka przez Prometeusza ${ }^{28}$. Rzeźbiarz, pragnąc zdecydowanie odróżnić osobę Stwórcy od Prometeusza, mógł specjalnie położyć akcent na Jego trójpostaci. Naiwny sposób przedstawienia dobrze odpowiada prostocie pierwszych antropomorficznych ujęć historii zbawienia. Warto tu przypomnieć ounośny opis Ireneusza:

"Homo /.../ secundum similitudinem Dei formatus est et per manus eius plasmatus est, hoc est per Fijgum et Spiritum, quibus et dixit: Faciamus hominem" ${ }^{2}$.

W najstarszej chrystologii /christologia pneumatica/ Syn Boży był często nazywany Duchem 30 .

27 Za "Trójcą" opowiadają się badácze: F. Gerke, Die christliche Sarkophage, Berlin 1940, 196; L. de Bruyne, jw., 175-182. Przeciwko: J. Engemann, jw., 164 oraz Y. Christe, A'propos du sarcophage à double registre récement découvert à Arles, "Journal des
Savants" 1975, 76-80.

L'imposition des mains, jw., 175-182. Znane są co najmniej dwa takie sarkofagi, z których jeden pochodzi z Muzeum Kapitolińskiego, sie stworzenia człowieka musiał jw. tabl. $20^{a}$. 0 tym, ze przy opiśriadczy wzmianka us ię nasuwać mit o Prometeuszu "Deum unicum esse, qui universa /Apologeticum 18, 2, CCL 1, 118/: struxerit /hic enim est verus Prometheus/". qui hominem de' humo

29 Adversus haereses IV Pr. 4, SCh 100, 390.

30 Ważne w tym zakresie wydają się stwierdzenia ks. bpa prof. dra hab. A. Nossola w artykule: Duch Swięty jako obecność Jezusa Chrystusa, CT 50/1980/ Pasc. 3, 5-24. Współczesna pneumatologicznie zorientowana chrystologia nawiązuje do źródeł patrystycznych, sens/. 
Dopiero późniejsze spory trynitarne mogły sprawić, że nie przedstawiano antropomorficznie Trójcy Swiętej aź do XII wieku, kiedy to nadano każdej z Osób inną postać. Antyczny antropomorfizm polegał - jak mi się wydaje - na tym, że Osoby nie były zróżnicoware, ponieważ 1stniała tylko jedna chrystologiczna wizja Boga wcielonego, który ukazywał 0jca/J 14, $9 / 1$ działał w Duchu.

Reasumując, sztuka nie miała 1 nie ma do dzisiaj żadnych jednoznacznie ustalonych sposobów przedstawiania osoby Ducha Swiętego. Symbole, znaki czy postacie, pod którymi sztuka chce oddać Osobę Ducha Swiętego, nogą być jako takie odczytane jedynie z całości kontekstu, w jakim wystęują.

Istnieją jednakże wyraźnie określone wyznaczniki poprawnej, jak sądzę, interpretacji, oparte bądź na Piśmie św., bądź na Tradycji przekazanej w pismach 0jców Kościoła, gdzie symbole gołg̨bicy 1 płomyków ognia ilustruja obraz,pod jakim rzeczywistość Ducha Świętego probowali oddać ewangeliści. Symbol światła oznaczajacy Ducha Swiętego w kompozycjach liczbowo-symbolicznych jest oczywistością Jego istoty. Postac człowieka nadana Duchowi Swiętemu, występująca zawsze $w$ grupie trzech Osób Boskich, powtarza wizerunek wcielonego Słowa.

Barbara Filarska - Lublin

\section{ICONOGKAPHY OF THE HOLY SPIRIT IN ANCIENT CHRISTIAN ART} /Summary/

ine Author briefly discusses three types of images interpreted as probable representations of the Holy Spirit: 1. Biblical symbols

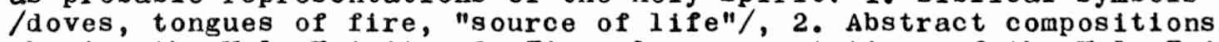
showing the Holy Trinity, 3. Figural representations of the Holy Trinity: a. typological, in the scene of the Three visiting Abraham at Mamre, b. direct, in the scene of the creation of Man. 